\section{REAPPEARANCE OF ENCKE'S COMET}

$\mathrm{T}^{\mathrm{T}}$ is quite possible that before the close of the next period of absence of moonlight in the early evening hours, the comet of Encke may be again detected with the large telescopes now to be found in our observatories. The mean motion determined by Glasenapp for the last perihelion passage at the end of December 187 I would bring the comet to the same point of its orbit about I875, April II.5, which was very nearly the date of passage through perihelion in 1842 . When it was last in aphelion, in the middle of August 1873,1 find its distance from the planet Jupiter would be $10^{\circ} 02$, and that from Saturn $77^{\circ}$, so that the perturbations during the present revolution are likely to be small; the comet still approaches near the orbit of Mercury in heliocentric longitude $123.7^{\circ}$ and latitude $6.8^{\circ} \mathrm{N}$, but it has not encountered that planet since November 1848 . Assuming, then, that the least distance from the sun will be attained at midnight on the I Ith of April next, we have the following positions of the comet during the period I have named :-

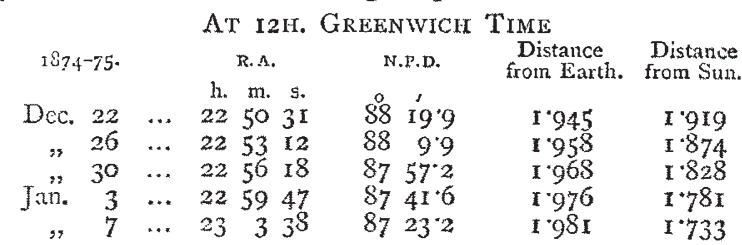

An acceleration or retardation of four days in the time of perihelion passage will not change the geocentric place more than fifteen minutes of arc, so that if the comet be within reach it may be easily found.

It will be interesting to learn what account some of the large reflecting telescopes with which many amateurs in this country have provided themselves, can give of the comet at this return.

The computation of the perturbations and preparation of an accurate ephemeris for 1875 is understood to be in the hands of Dr. von Asten, of Pulkova; but I am not aware that the results have yet been given to astronomers.

Mr. Bishop's Observatory, Twickenham, Dec. I4 J. R. HIND

\section{NOTES}

Sizicr viri last weak's note, we understand that the whaing stcamci blowlhonul, of Greenock, has been purchased as the chief ressel of the new Arctic Expedition. Other whalers have been cimmined by Sir Leopold M.'Clintock, but none have been dicmed suitable. The fitwilhoum is a screw steamer, whose engines are nominally 96 horse-power; she is barque-rigged, two years old, strong, sound, and well appointed, and handy either under steam or canvas. It is announced that the vessel chosen to be the consort of the steam-whaler Bloodhound in the forthcoming expedition is Her Majesty's ship Alert. She is a five-gun steam-sloop of $75 \mathrm{r}$ tons old measurement, and 100 horse-power nominal. The Alort has been docked at Portsmouth and will undergo a thorough survey. Active preparations for the equipment of the ships will soon commence, but the start will not be made until the latter part of June of next year, as it is considered merely waste of labour and time to push across the north water until the ice has had time to melt and drift out from Smith's Sound. A request has been made by the Foreign Office that the Danish Government will permit their agents at Disco, Proven, and Upernavik to collect hunters, dogs, and dog-drivers for the Arctic Expedition. Capt. Nares is expected to arrive in this country about the end of January, 1875 . The Committee for making arrangements with respect to the Expedition sat on Tuesday and Wednesday at the Admiralty for the purpose of deciding on the provisions and clothing to be supplied to the members of the expedition. They have been occupied hitherto with details as to the route.

Apropos of the possible biological results of the Arctic Expedition, we may recall to recollection a few additional details to those given last week of what was accomplished by the Polaris. The northern limit actually reached was $82^{\circ} 16^{\prime}$. Yet at this extreme latitude fifteen species of plants were collected, five of which were grasses. Twenty-six musk oxen were shot in lat. $81^{\circ} 3^{\prime}$. Dr. Bessels also made a fair collection of insects, principally flies and beetles, two or three butterflies and mosquitos; and birds of seventeen different kinds were shot in $82^{\circ}$, including two Sabine gulls and an Iceland snipe.

DURING the whole of the past week the members of the French Academy of Sciences have had frequent meetings to receive the telegrams from the several French Transit stations. The first, from Janssen, relieved them of a great anxiely, and was published instantly. The most extraordinary measures have been taken to secure the safe transmission of the results of the observations at French stations. The chief of each station is ordered to make four copies of his observations. One is to be left under a cairn, or a tree (if any in the country), or in an excavation, the site to be described in a letter to the Institute; the second is to be handed over to the captain of the first French ship that is met, with instructions to bring it himself to the Institute; the third is to be delivered to the nearest French consul, agent, or ambassador; the fourth is to be kept by the chief of the station himself.

MM. FizeAu and Cornu, authorised by M. Leverier, have been making an experiment of the highest importance at the Paris Observatory, the results of which were to be given at Mon. day's sitting of the Academy. The two sazants have been measuring the velocity of transmission of light, by experiments carried on between the Observatory and Montihéry. The light sent to Montlihery is reflected and returns to the Observatory, the distance there and back being 22,000 yards. The experiment has never hitherto been made on so grand a scale, nor with such precautions; ten powerful instruments were used.

HuR Majesty's ship Basilisk, which has just returned to England after a commission of nearly four years, has (the Times states) surveyed about 1,200 miles of coast line, added at least twelve first-class harbours, severol navigable rivers, and more than one hundred islands, large and smail, to the chart ; and, lastiy, has been abic to announce the existence of a new and shorter route between Australia and China. Till these bixsilisk discoveries were made, a large archipelago of islands (some as large as the Isle of Wight, and densely populated), a rich fertile country, intersected by navigable rivers, and inhabited by a semicivilised Malay race, remained unkrown to us. After the news of this ship's first discoveries reached England, Lieut. Dawson, R.N. (Admiralty Surveyor), was sent out to join her, and she was ordered to complete and follow them up. This has been done with perfect success, and the whole of the previously unknown shores of Eastern New Guinea have been carefully surveyed, and the route above referred to opened up. The principal part of this work of discovery and surveying has been performed by the captain and officers in small open boats, detached from the ship in some instances for many weeks, and among savages who had never before seen a white face. It is stated that two lorty mountains, about 11,000 feet high, facing each other on the north-east coast of New Guinea, have been named "Mount Gladstone" and "Mount Disraeli." This intelligence will have an interest of rather a tantatising kind for naturalists. There is hardly any part of the world more pro. mising to students of the geographical distribution of living forms than that which the Basilisk has surveyed. Collections, more especially of the plants, might doubtless often have been made. 